\title{
Determinant of Rule-Bounded Organizational Citizenship Behavior (ROCB): The Role of Employee Engagement as a Mediating Variable (The Study on the Employees of PT Bintan Inti Industrial Estate)
}

\author{
Brian Dwi Kurniawan ${ }^{1}$, Syahrizal ${ }^{2}$ \\ ${ }^{1}$ University of Padang, Padang, Indonesia, $₫$ briandwikurniawan16@gmail.com \\ 2 University of Padang, Padang, Indonesia, \syahrizal@fe.unp.ac.id
}

\begin{abstract}
The purpose of this study was todetermine the effect of the rule-bounded organizational citizenship behavior (ROCB) with employee engagement as a mediating variable. This research was conducted at PT. Bintan Inti Industrial Estate, the samples in this study amounted to 103 employees, consisting of eight (8) work units. The analysistestis the analysis of SEM (Structural Equation Model) by using PLS analytical tools (Partial Least Square). The results of this study show that: 1) Oorganizational climate has a positive effect on ROCB. 2) Interpersonal Communication has a positive effect on ROCB.3) Organizational climate has a significant positive effect on employee engagement. 4) Interpersonal communication has a significant positive effect on employee engagement. 5) Employee engagement has a significant positive effect on ROCB.6) Organizational climate has a significant positiveeffect on ROCB with employee engagement as amediator variable. 7) Interpersonal communication has a positive significant effect on ROCB with employee engagement as a mediating variable. These results can be interpreted that the organizational climate, interpersonal communication, employee engagement, and rule-bounded organizational citizenship behavior arevaluable components to an organization. These components can be important factors to improve employee performances and organizational goals.
\end{abstract}

Keywords: rule-bounded organizational citizenship behavior (ROCB), employee engagement, organizational climate, interpersonal communication

\section{Introduction}

Organizational citizenship behavior (OCB) as individual behavior that arises from own consciousness and indirectly recognized by a company or organization by directly givingan award or salary. OCB directly impacts on the effective functioning of an organization (Bies, 1989; Podsakoff et al., 2009; Silva \& Madhumali, 2014). OCB as one of the factors that influence the effectiveness and success of an organization (Jafari \& Bidarian, 2012; Deery et al., 2017). Researchers have identified the importance of OCB and try to dedicate their attention to the aspects of employees behavior for better organizational success and performance (Konovsky \& Pugh, 1994; Podsakoff et al., 2000; Bettencourt et al., 2001; Rioux and Penner, 2001; Iqbal et al., 2012). OCB is an interesting subject of study in the modern times as it relates to the fundamental role of employment and workplace with an increased focus on strategic HR (García-Carbonell et al., 2014) and the collective cultural shift in which an organization operates. Given that OCB promotes productivity, efficiency, and effectiveness of the organization as a whole (Lo et al., 2006).

The extra role of an employee in a company can be indicated by several things such as helpingcoworkers outside the main task. In this case, many researchers still see that extra role as voluntary behavior that arises from the employee. A new question appears, What if the employee exhibits a behavior because the job role requires him to do so or he is paid to do so? What if climate and communication within an organization influence employees to act in a certain way? This study was 
developedbased on a previous study conducted by Agarwal (2016). This study differs from the previous studies which focused only on one dimension of the more specific indicators. The dimension is known as rule-bounded organizational citizenship behavior (ROCB).

According to Agarwal (2016), Rule-bounded organizational citizenship behavior (ROCB) is a behavior that arises because of the role given by a company where someone works. This role is taken by the employees as part of their responsibilities. This role will lead to behaviors of helping others and will ultimately result in benefits for other employees and the company.

As with the previous OCB, ROCB overlooked by a company will have an impact on the company. It may specifically affects the company's performance in terms of: encouraging an increased productivity of managers and employees, encouraging the use of resources of the company for more specific goals, reducing the need to use the organization's resources that are rareon the maintenance function, facilitating coordination activities among team members and working groups, further enhancing the company's ability to maintain and retain qualified employees to make the work environment as a more pleasant place to work, improving the stability of the company's performance by reducing the diversity of variations in the performance of each unit of the company, increasing the company's ability to adapt toward environmental change.

When an urge to become the behavior is part of the role, then other employees will have anindirect responsibility to the achievement of company goals. It can be done in the way of improving organizational climate, upgradingjustice and prosperity, or enhancing the channels of communication with employees (Agarwal: 2016).

The contribution of this study is the use of company perceptions related to the role of human resource (HR) practices. This research focuses on the impact on employee behavior that is mediated by employee engagement. This research has a difference with the research that has been done before because this study focuses more on the relationship between organizational climate, interpersonal communication that affects the behavior of employees who are bound by rules. While previous research is more directed at developing the dimensions of citizenship behavior of voluntary organizations. With a new view of the behavior of citizenship organizations, this research is expected to provide benefits for companies and future researchers to develop. According to the researchers, the next ROCB variable will be an interesting variable to be explored to have a direct effect on the company. The study also provides a good understanding of organizational climate and interpersonal communication related to employee behavior. Based on existing theories and studies on employee involvement, it is hypothesized that employee positive perceptions of organizational climate and interpersonal communication can strengthen the relationship between employee involvement and ROCB. In the following paragraphs are conceptual development, methods, results, discussions, conclusions and recommendations

\section{Conceptual Development and Hypotheses Of Research Organizational Climate}

Litwin and Stringer (1968) in Brown and Brooks (2002) define organizational climate as a set of steps regarding the work environment that are felt both directly and indirectly by people who live and work in the organization's work environment and are considered to influence behavior. Francisco and Andres (2017) a positive organizational climate promotes a positive attitude about the work they do. In addition, the organizational climate is one of the most significant determinants of the attitudes and behavior of individuals and groups within institutions (Garcia-Garcia et al., 2011). In measuring organizational climate, there are several opinions that reveal the related dimensions of this climate organization.

It is important to create an organizational climate because it is a person's perception of what is provided by the organization and is used as a basis for determining the behavior of the next members. Stringer (in Saleh, 2015) adds organizational climate as something that can be measured in a work environment which directly or indirectly affects the employee and his job. Organizational climateis 
related to the creation of a conducive work environment. This research took five dimensions of the organizational climate. The dimensions include: (1) Structure, (2) Responsibility, (3) Reward, (4) Warmth, (5) Support.

\section{Interpersonal Communication}

Within an organization, communication flows from individual to individual in face-to-face and group settings. Such flow is called interpersonal communication, which can vary from direct orders to regular expressions. Interpersonal communication is the primary means of managerial communication, on ordinary days, a lot of manager communication is going in face-to-face interaction. (Gibson, Ivancevich, Donnelly, Jr., and Konopaske: 2016).

In other words, interpersonal communication is a process of exchanging information between an inidivual with at least another individual or generally between two people who can immediately find out the feedback, in other words that interpersonal communication is to directly form relationships with the other people. The indicators of interpersonal communication according to De Vito (2007) are: openness, empathy,supportiveness of positiveness, equality.

\section{Employee engagement}

This despite the fact that recent research found strong evidence that organizational identification is a unique construct that can be distinguished from other constructs of attitude, which acts as a positive influence on other attitudes (eg, organizational commitment, job satisfaction) and behavior. (eg extra role performance) (Lee, Park, \& Koo, 2015).In addition, the employees involved experienced a high level of enthusiasm, and were very self-identified with their work (Karanika-Murray, Duncan, Pontes, \& Griffiths, 2015).These studies show that employees involved have high levels of energy and mental endurance, and are therefore willing to invest in efforts and stay in their jobs. (Zhang, Y., Guo, Y., \& Newman, A. 2017).

Dvir, Eden, Avolio, and Shamir: 2002 (Sarangi, 2012) also state that employee engagement is defined as an active sense of belonging between an employee with a job or organization, in the sense that the employee proves a sense of attachment to it by actively engaging in the job job, has a high sense of initiative and responsibility. In outlining employee engagement, Schaufeli and Bakker (in Zulyanti. 2014) state that this engagement is influenced by three (3) dimensions, namely vigor, dedication, and absorption.

\section{Rule-bounded Organizational Citizenship Behavior (ROCB)}

The concept of "ROCB" is one of the parts of the previous OCB, which was developed by a researcher named Agarwal in 2016. According to Agarwal (2016), Rule-bounded organizational citizenship behavior (ROCB) is a behavior that arises because of the role given by a company where someone works. This role is taken by the employees as part of their responsibilities. This role will lead to behaviors of helping others and will ultimately result in benefits for other employees and the company.

In this study, the indicators that will be used are based on the phenomenon of the companies that will be examined, so that the indicators have become more focused on the problems that appear. Those indicators include: contributions, responsibilities, implementation of the applicable rules, supporting friends in work, establishing good communication between employees and employers. 


\section{Conceptual framework}

Based on the description above, the conceptual framework can be described as follows:

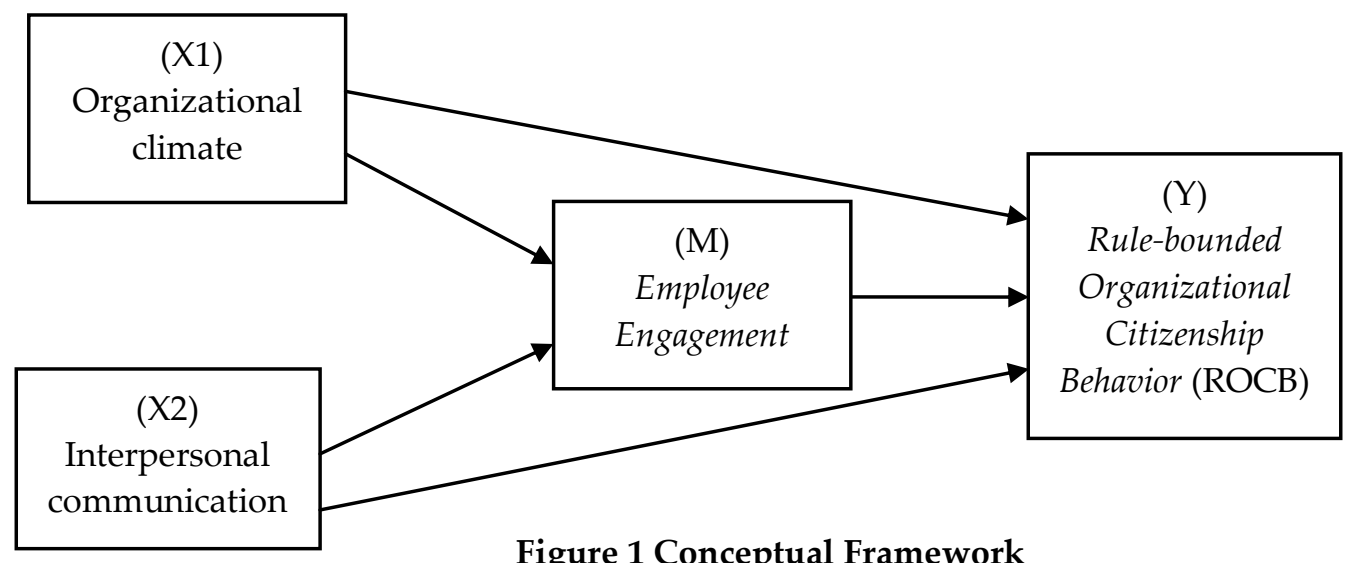

Figure 1 Conceptual Framework

\section{Organizational climate, Interpersonal communication,Employee Engagement and ROCB}

Process climates that have been the focus of recent research include ethical climate (Martin \& Cullen 2006, Mayer et al. 2009, Schminke et al. 2005), empowerment climate (Chen et al. 2007, Seibert et al.2004), voice climate (Morrison et al. 2011), and climate for initiative (Baer \& Frese 2003, Michaelis et al. 2010). The study of these from a climate perspective could yield new insights into the sets of contextual process variables that are their correlates and perhaps their antecedents. In sum, the change to a strategic outcome and process focus for climate research has significantly improved not only the validity of climate research but also the understanding of the contexts that likely yield these focused climates. As such, the development of this more focused approach has resulted in the climate construct being more available to practitioners because it literally has focused on important organizational processes and outcomes and has indicated specific practices and behaviors thatmight serve as interventions in organizations to enhance performance in those areas (Burke 2011).

Schneider et al. (2011) have proposed that process climates might be conceptualized as a foundation for outcome climates. That is, when workers perceive that their organization is concerned about their well-being through its emphasis on fairness, diversity, ethics, trust, and so forth, they are more amenable to the efforts of management to focus on strategic outcomes of value to the organization.

Human resources (in the form of a positive organizational climate) encourage positive attitudes about supported work (Francisco and Andres; 2017). Organizational climate considered in addition, organizational climate is one of the most significant determinants of individual and group attitudes and behaviors in relationships (Garcia-Garcia et al., 2011)

When employees experience satisfaction in communication at work, their satisfaction is likely to be expressed by engaging in extra-role behavior (Bolino \& Turnley, 2003). The quality of working relationships and trust with their supervisor (and organization) will be promoted, which implies that employees may perceive greater levels of justice (Niehoff \& Moorman, 1993). With a fair working environment, employees are more inclined to form close working relationships, become motivated and perform in ways which benefit the individuals and organizations by reciprocation (Cropanzano and Mitchelle, 2005, Karriker and Williams, 2009, Zapata-Phelan et al., 2009).

The more interaction and relationships between employees in a continuous manner, will be realized in the form of social support, reciprocal protection, self-disclosure and others (Forsyth, 2010). In addition, 
interpersonal communication within the team also helps to support coordination between members to achieve goals (Harris \& Nelson, 2008).

The development of human resources now is recognized as a pivotal process in organizations (Vince 2003). HRD functions are responsible for dealing with the most important organizational assets; employees and knowledge (Gold, Rodgers, and Smith 2003).

Employee engagement is energy, involvement and self efficacy in performing work which is contrary to burnout dimensions that are exhaustion, cynicism and inefficacy (Maslach et., 2001).Employee engagement serves as direct predictor of organization's financial Performance and success (Bates 2004; Baumruk 2004; Harter et al. 2002; Richman 2006). In today's workplace enormous engagement gap can be seen (Bates 2004; Johnson 2004; Kowalski 2003).

The most comprehensive study on this issue was done by (Perrin, 2007), and according to him only $14 \%$ employees are actively engaged in their work.Employee engagement leads to organizational citizenship behavior as it focuses on employee involvement and secures their commitment which definitely lies outside the prescribed parameters of anyorganization. Rukkhum (2010), states a positive relationship between employee engagement and Organizational Citizenship Behavior (OCB). All these dimensions of OCB are indeed characteristic of employee's active engagement, but the OCBdimension which most strongly co-relates with employee engagement is "taking initiatives individually" which means going an extra-mile (Dicke, 2010).

With the presence of employees involved in the company, this company has positive work. This is because related to the representation of workers who have a good attachment to the company where he works, then they will have greater enthusiasm for work, even more discussing the main tasks contained in their employment contract (Meida, 2010).

Research conducted by Baumruk and Gorman, (2006) revealed that if employees have a high sense of attachment with the company, it will improve behavior that will improve performance where employees can voice their opinions to a higher level through well-built communication, and ultimately will provide positive input for the company.

Collectively, the findings of this literature lead to the seven hypotheses that are built in this study:

$\mathrm{H}_{1}$ : Organizational climate has a positive effect on the rule-bounded organizational citizenship behavior (ROCB)

$\mathrm{H}_{2}$ : Interpersonal communication has a positive effect on the rule-bounded organizational citizenship behavior (ROCB)

$\mathrm{H}_{3}$ : Organizational climate has a positive effect on employee engagement

$\mathrm{H}_{4}$ : Interpersonal communication has a positive effect on employee engagement

$\mathrm{H}_{5}$ : Employee engagement has a positive effecton rule-bounded organizational citizenship behavior (ROCB)

$\mathrm{H}_{6}$ : Organizational climate with employee engagement as a mediator variable have a positive effect on the rule -bounded organizational citizenship behavior (ROCB)

$\mathrm{H}_{7}$ : Interpersonalcommunication with employee engagement as a mediator variable have a positive effect on the rule-bounded organizational citizenship behavior

\section{Methods}

The population in the study were all employees of PT BIIE, totaling 169 employees consisting of eight work divisions, namely (1) Finance (2) Admin (3) CRS (4) Liaison (5) Estate (6) Utilities (7) Procurement (8 ) GMOs. Respondents in this study consisted of 103 employees. Sampling was done using the clusster proportional sampling method. This method takes samples in each class or group according to portions. The questionnaire distributed to 103 respondents made it all back and all returned questionnaires could be analyzed. 
From the 103 respondents, 76 respondents male $(73.8 \%)$. The majority of employees are age $41-50(\mathrm{n}=$ $39,37.9 \%)$. The majority of respondents are high school graduates $(\mathrm{n}=90,87.4 \%)$. Table 1 presents the demographic characteristics of the 103 respondents.

Table 1 Sample demographic variables.

\begin{tabular}{|c|c|c|c|}
\hline Variables & Values & Frequency & Percentage \\
\hline \multirow[t]{2}{*}{ Gender } & Female & 76 & $73.8 \%$ \\
\hline & Male & 27 & $26.2 \%$ \\
\hline \multirow[t]{5}{*}{ Age } & 18 - 20 years & 8 & $7.8 \%$ \\
\hline & 21 - 30 years & 18 & $17.5 \%$ \\
\hline & $31-40$ years & 27 & $26.2 \%$ \\
\hline & $41-50$ years & 39 & $37.9 \%$ \\
\hline & $>50$ years & 11 & $10.7 \%$ \\
\hline \multirow[t]{3}{*}{ Education } & High school degree & 90 & $87.4 \%$ \\
\hline & Associate's degree & 4 & $3.9 \%$ \\
\hline & Bachelor's degree & 9 & $8.7 \%$ \\
\hline \multirow[t]{4}{*}{$\begin{array}{l}\text { Experience at this } \\
\text { organization }\end{array}$} & $1-5$ years & 28 & $27 \%$ \\
\hline & $6-10$ years & 23 & $22 \%$ \\
\hline & 11-15 years & 20 & $19 \%$ \\
\hline & $>16$ years & 32 & $32 \%$ \\
\hline \multirow[t]{8}{*}{ Division of work } & Finance & 5 & $5 \%$ \\
\hline & Admin & 6 & $6 \%$ \\
\hline & CRS & 3 & $3 \%$ \\
\hline & Liaison & 8 & $8 \%$ \\
\hline & Estate & 13 & $13 \%$ \\
\hline & Utilities & 64 & $62 \%$ \\
\hline & Procurment & 3 & $3 \%$ \\
\hline & GMO & 1 & $1 \%$ \\
\hline
\end{tabular}

This study uses data obtained through the respondents, in which the respondents will give verbal or written responses as responses to the statements given. The type of data used in this study are primary data, which is respondents' opinion data toward organizational climate variable (X1), interpersonal communication $(\mathrm{X} 2)$, employee engagement $(\mathrm{M})$ and ROCB $(\mathrm{Y})$ which are directly obtained from the responses to the questionnaires that were distributed to the employees of PT Bintan Inti Industrial Estate (BIIE).

\section{Data Analysis}

The types of research used in this study are descriptive and causative. This study examines the effect of independent variables (organizational climate and interpersonal communication) toward the dependent variable (ROCB). In addition, this study examines the effect of the mediator variable (employee engagement).

Data analysis and hypothesis testing in this study use SEM (Structural Equation Model) by using analytical tools of PLS (Partial Least Square). The reasoni i use PLS modeling can be based on (1) theory, (2) the results of empirical research, (3) analogies, relationships between variables in other fields of science, (4) normative things, in part, (5) rational relationships others. So that the theoretical basis for PLS can be strong, weak and even explorative. 
Structural equation modeling (SEM) is a multivariate analysis technique which combines factor analysis and path analysis so that it allows the researchers to simultaneously test and estimate the relationship between multiple exogenous and endogenous variables by many factors (Gefen et al., 2000). SEM is divided into two types, which are the Covariance-based Structural Equation Model (CBSEM) and Partial Least Square-Structural Equation Model (PLS-SEM).

\section{Results and Discussion}

Hypothesis testing is done by using the model of Structural Equation Modeling with the technique of PLS (Partial Least Square) to test the effect of each of the organizational climate and interpersonal communication variables on ROCB through employee engagement.

Before the hypothesis test, it is necessary to know the results of the validity and reliability tests. Discriminant Validity is an analysis to determine construct validity by evaluating AVE (Average Variance Extracted) Root, by comparing correlations between constructs and other constructs. The model has sufficient discriminant validity if the root AVE for each construct is greater than the correlation between constructs and other constructs in the model on PLS output can be shown in Table 2:

Table 2 Diskriminan Validity

\begin{tabular}{lccccc}
\hline & $\begin{array}{c}\text { Empl. } \\
\text { Engagement }\end{array}$ & $\begin{array}{c}\text { Organizational } \\
\text { Climate }\end{array}$ & $\begin{array}{c}\text { Interpersonal } \\
\text { Communication }\end{array}$ & ROCB & AVE \\
\hline $\begin{array}{l}\text { Employee } \\
\text { engagement }\end{array}$ & $\mathbf{0 . 7 8 6 ^ { * }}$ & & & $\mathbf{0 . 6 1 8}$ \\
\hline $\begin{array}{l}\text { Organizational } \\
\text { Climate }\end{array}$ & 0.571 & $\mathbf{0 . 7 3 7 ^ { * }}$ & & $\mathbf{0 . 5 4 3}$ \\
\hline $\begin{array}{l}\text { Interpersonal } \\
\text { Communication }\end{array}$ & 0.546 & 0.494 & $\mathbf{0 . 8 0 8 ^ { * }}$ & & $\mathbf{0 . 6 5 2}$ \\
\hline \multicolumn{1}{c}{ ROCB } & 0.693 & 0.645 & 0.695 & $\mathbf{0 . 7 9 8 ^ { * }}$ & $\mathbf{0 . 6 3 7}$ \\
\hline
\end{tabular}

Based on the table above it can be concluded that the AVE root in all constructs is higher than the correlation between these variables and other variables as in table 2 . Thus all indicators are declared valid.

Testing the reliability of construct data can be seen from the composite reliability value. If a construct that has a composite reliability value is above 0.70 then the stated construct is reliable. the results of the research obtained from the results of processing using PLS:

Table 3 Composite Reliability

\begin{tabular}{lcc}
\hline & Cronbach's Alpha & $\begin{array}{c}\text { Composite } \\
\text { Reliability }\end{array}$ \\
\hline Empl. Engagement & 0.876 & 0.906 \\
\hline Organizational Climate & 0.893 & 0.914 \\
\hline Interpersonal Communication & 0.865 & 0.903 \\
\hline ROCB & 0.936 & 0.946 \\
\hline
\end{tabular}


Based on table 3, it can be concluded that all the questions used are realible. In this study each question item has different realible values. To be declared realible, each variable must have a composite reability value above 0.70 .

Hypothesis testing can be carried out by considering the level of significance and the parameters of the path between the latent variables. The hypothesis was proposed to determine the relationship between each of the hypothetical constructs. Decision-making is based on the relationship direction and significance of the test model between the constructs shown in Table 4.14 which are the output result of the inner weight with the help of PLS 3.2.7 software. The output results of PLS 3.2.7 found bootstrahaling value results with the 103 samples which produce the estimated and probability valuewhich are shown in Figure 2.

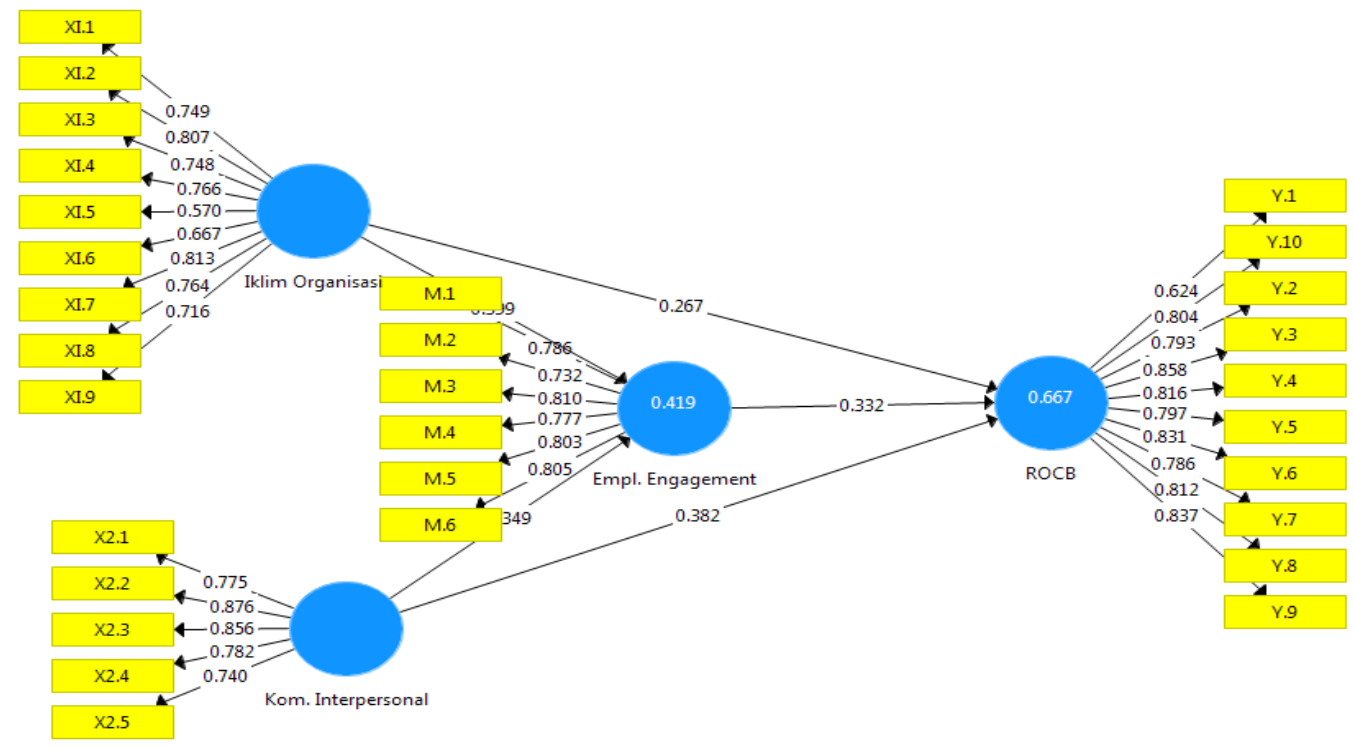

Figure 2 Structural Model

The results of this inner weight indicate a correlation between constructs that connect variables which form a hypothesis.

Table 4 The Direct Effect Between Constructs

\begin{tabular}{lcccl}
\hline & $\begin{array}{c}\text { Original } \\
\text { Sample (O) }\end{array}$ & $\begin{array}{c}\text { T Statistics } \\
(\mid \mathbf{O} / \text { STDEV } \mid)\end{array}$ & $\begin{array}{c}\text { P } \\
\text { Values }\end{array}$ & Information \\
\hline Organizational Climate -> ROCB & 0.267 & 2.242 & 0.025 & $\begin{array}{l}\text { His } \\
\text { supported }\end{array}$ \\
\hline $\begin{array}{l}\text { Interpersonal Communication -> } \\
\text { ROCB }\end{array}$ & 0.382 & 3.844 & 0.000 & $\begin{array}{l}\mathrm{H}_{2 i} \\
\text { supported }\end{array}$ \\
\hline $\begin{array}{l}\text { Organizational Climate -> Empl. } \\
\text { Engagement }\end{array}$ & 0.399 & 3.148 & 0.002 & $\begin{array}{l}\text { H3is } \\
\text { supported }\end{array}$ \\
\hline $\begin{array}{l}\text { Interpersonal Communcation -> } \\
\text { Empl. Engagement }\end{array}$ & 0.349 & 3.086 & 0.002 & $\begin{array}{l}\text { H4is } \\
\text { supported }\end{array}$ \\
\hline Empl. Engagement -> ROCB & 0.332 & 3.042 & 0.002 & $\begin{array}{l}\text { H5is } \\
\text { supported }\end{array}$ \\
\hline
\end{tabular}

The test results analysis can discover its direct effect. Table 4 shows the direct effect on the dependent variable. 
The test results of $\mathrm{H}_{1}$ can find outthe direct effect of organizational climate on employee engagement which has the path coefficient of 0.267 and the calculated $t$ equals to $2.242>1.96$ and p-value of 0.025 $<0.05$, thus the relationship is significant. Therefore, organizational climate has a positive significant effect on ROCB. It means that the better the climate of the organization, then the more ROCB of employees will increase. For that reason, the first hypothesis of this study is supported.

The test results of $\mathrm{H}_{2}$ can find out the direct effect ofinterpersonal communication on employee engagement which has the path coefficient of 0.382 and the calculated t equals to 3.844>1.96 and p-value of $0.000<0.05$, so the relationship is significant. Thus, interpersonal communication has a significant positive effect on employee engagement. It means that the better theinterpersonal communication,then the more employee engagement of employees will increase. Therefore, the second hypothesis of this study is supported.

The test results of $\mathrm{H}_{3}$ can find out the direct effect oforganizational climate on ROCB which has the path coefficient of 0.399 and calculated $t$ equals to 3.148> 1.96 and p-value of $0.002<0.05$, so that the relationship is significant. As a result, organizational climate has a significant positive effect on employee engagement. It means that the better the existing organizational climate, then the more employee engagement of employees will increase. Hence, the third hypothesis of this study is supported.

The test results of $\mathrm{H}_{5} \mathrm{can}$ find out the direct effect of interpersonal communication on ROCB which hasthe path coefficient of 0.349 and calculated t equals to 3.086 $>1.96$ and p-value of $0.002<0.05$, then the relationship is significant. Consequently, interpersonal communication has a positive significant effect on ROCB. It means that the better the interpersonal communication, then the more ROCB will increase.That being the case, the fourth hypothesis of this study is supported.

The test results of $\mathrm{H}_{5} \mathrm{can}$ find out the direct effect of employee engagement on ROCB which has the path coefficient of 0.332 and calculated $t$ equals to 3.042> 1.96 and $p$-value of $0.002<0.05$, so the relationship is significant. As a consequence, employee engagement has a positive significant effect on ROCB. It means that the better the employee engagement of employees, then the more ROCB will increase. Thus, the fifth hypothesis of this study is supported.

Table 5 The Indirect Effect Between Constructswith SOBEL TEST

\begin{tabular}{lcccc}
\hline & $\begin{array}{l}\text { Original } \\
\text { Sample (O) }\end{array}$ & $\begin{array}{l}\text { T Statistics } \\
\text { (SOBEL TEST) }\end{array}$ & $\begin{array}{l}\text { P Values } \\
\text { Valnformation }\end{array}$ & In \\
\hline $\begin{array}{l}\text { Organizational Climate -> Empl. } \\
\text { Engagement -> ROCB }\end{array}$ & 0.132 & 2.18686 & 0.0287 & $\mathrm{H}_{6}$ is supported \\
\hline $\begin{array}{l}\text { Interpersonal Communication } \rightarrow \\
\text { Empl. Engagement }->\text { ROCB }\end{array}$ & 0.116 & 2.16866 & 0.0301 & $\mathrm{H}_{7}$ is supported \\
\hline
\end{tabular}

The test results with Sobel Test can find out the indirect effect between the dependent variable. Table 5 shows the indirect effect on the dependent variable.

In the indirect effect testing with Sobel TEST, the indirect effect of organizational climate on theROCB can be known through employee engagement which hasthe path coefficient of 0.132 and calculated $t$ equals to $2.18686>1.96$ and $\mathrm{p}$-value of $0.0287<0.05$ thus the relationship is significant. Therefore, employee engagement is a variable that mediates the relationship between organizational climate toward ROCB, with the magnitude of the indirect effect of 0.132. It means that the better the climate of the organization, then the more employee engagement will increase so thatits ROCB will be getting better. As a result, the sixth hypothesis which states $\mathrm{H}_{6}$ : "Organizational climate with employee engagement as a mediator variable has a positive effect on the rule-bounded organizational citizenship behavior (ROCB)" is supported. 
The indirect effect of interpersonal communication on ROCB through employee engagement hasthe path coefficient of 0.116 and calculated $t$ equals to $2.16866>1.96$ and p-value of $0.0301<0.05$ so that the relationship is significant. Consequently, employee engagement is a variable that mediates the relationship between interpersonal communication toward ROCB, with the magnitude of the indirect influence of 0.116 . It meansthat the better the employee engagement, then the more the rule-bounded organizational citizenship behavior (ROCB) of employees will be getting better. Hence, the seventh hypothesis which states $\mathrm{H}_{7}$ : "Interpersonal communication with employee engagement as a mediator variable has a positive effect on the rule-bounded organizational citizenship behavior (ROCB)." Is supported.

\section{Discussion}

Previous research conducted by Agarwal (2016) validated three dimensions of OCB. Data supports consideration DOCB as one dimension and two new dimensions OCB proposed. This study provides a set of $\mathrm{DOCB}, \mathrm{NOCB}$, and ROCB indicators that behave as expected in terms of statistical and theoretical criteria.Human resources (in the form of a positive organizational climate) encourage positive attitudes about supported work (Francisco and Andres; 2017). Organizational climate considered in addition, organizational climate is one of the most significant determinants of individual and group attitudes and behaviors in relationships (Garcia-Garcia et al., 2011)

The better the condition of the organizational climate that exists in a company such as the clear division of labor, the people feel fairly appreciated, the existence of motivation and recognitionfrom the company to all employees for their performance, then the ROCB will increase. Employees who have a high ROCB will tend to be willing to contribute ideas in the workplace because theyfeel that it is already a part of their duties.

The more interaction and relationships between employees in a continuous manner, will be realized in the form of social support, reciprocal protection, self-disclosure and others (Forsyth, 2010). In addition, interpersonal communication within the team also helps to support coordination between members to achieve goals (Harris \& Nelson, 2008).

The role of interpersonal communication that goes well and intensively by putting an emphasis on the aspects of balanced quantity and quality, will create strong interpersonal relationships between superiors and subordinates as well as among fellow employees, so that openness and trust are gained from the communication process that can also determine changes in attitudes and behavior within an organization. In its practice, a change in attitude and behavior of the interpersonal communication processes within the organization can be in the form of realization of an attitude that is expected to appear from the employee himself, which is the high motivation to work with such behavior can be emulated by other employees.

Employee engagement is energy, involvement and self efficacy in performing work which is contrary to burnout dimensions that are exhaustion, cynicism and inefficacy (Maslach et., 2001). Employee engagement serves as direct predictor of organization's financial Performance and success (Bates 2004; Baumruk 2004; Harter et al. 2002; Richman 2006). In today's workplace enormous engagement gap can be seen (Bates 2004; Johnson 2004; Kowalski 2003).

Research conducted by Baumruk and Gorman, (2006) revealed that if employees have a high sense of attachment with the company, it will improve behavior that will improve performance where employees can voice their opinions to a higher level through well-built communication, and ultimately will provide positive input for the company.

A good relationship between leaders and subordinates, a leader who gives trust to subordinates in every task completion, there are mutual trust and openness among employees towardthe job information and there are also assistance and encouragement of superiors when faced with a difficult task, then the employee engagement of employees will increase, so that the employees have high spirits in their work, 
on the other hand, the manager is willing to give a good example to his employees and good cooperation exists.

Intense communication will make a person become more loyal so that it can lead to extra behavior in doing obligatory tasks, such as providing either input or bridge for the resolution ofconflicts within the company. These behaviors are expected by the company as the given roles and responsibilities.

\section{Conclusion}

Based on the results of the data analysis and discussion regarding the effect of organizational climate and interpersonal communication on ROCB at PT BIIE. It can be summed up as follow:

1. Organizational climate has a positive effect on the rule-bounded organizational citizenship behavior (ROCB). It means that the better the organizational climate, then the morethe ROCB will increase.

2. Communication Interpersonal has a positive effect on the rule-bounded organizational citizenship behavior (ROCB). It means that the better interpersonal communication, then the more the ROCB will increase.

3. Organizational climate has a significant positive effect on employee engagement. It means that the higher the organizational climate, then the morethe employee engagement of employees will increase.

4. Interpersonal communication has a significant positive effect on employee engagement. It means that the better the interpersonal communication, then the more the employee engagementof employees will increase.

5. Employee engagement has a positive significant effect on the rule-bounded organizational citizenship behavior (ROCB). It means that the higher the employee engagement, then the more the ROCB will increase.

6. Organizational climate has a positive significant effect on ROCB with employee engagement as a mediator variable. It means that the better the organizational climate, then the more the employee engagement of employees will increase so thatthe ROCB of employees will improve.

7. Interpersonal communication has a positive significant effect on ROCB with employee engagement as a mediating variable. It means that the better the interpersonal communication of employees of PT BIIE, then the morethe employee engagement of employees will increase so that the ROCB of employees will improve.

\section{Recommendation for Further Research}

This study reveals positive relationships between organizational climate, interpersonal communication, with employee engagement as a mediating variable toward ROCB, this shows that employee engagement is not limited to the role performance. However, further research is needed to further explore the variables or indicators that affect ROCB, especially in a broader context. In addition, it is important to explore more the reason why employee engagement is positively related to the performance of in-role and extra-role: due to the shift of the economic and community power that lead employees to broadly define their formal role or perhaps because they efficiently perform formal roles, leading to attempts to go further with extra-role performance (Christian, Garza, and Slaughter, 2011).

Future research related to ROCB needed to focus on the consequences of ROCB on the performance of individuals, groups, and organizations, as well as the results for employees who conduct ROCB (Podsakoff et al., 2009; Spitzmuller, Van Dyne, and Ilies 2008). Recommendations are also made on the need to conduct research on ROCB in different cultural contexts so that more companies understand the importance of applied ROCB in the achievement of more maximal goals. 


\section{References}

Agarwal, Promila. (2016) "Redefining the organizational citizenship behaviour" International Journal of Organizational Analysis. Vol. 24 (5): 956-984.

Balakrishnan, C., \& Masthan, D. (2013). Impact of internal communication on employee engagement - A study at Delhi international airport.International Journal of Scientific and Research Publications, 3(8).

Barron, P., Leask, A., \& Fyall, A. (2014). Engaging the multi-generational workforce in tourism and hospitality. Tourism Review, 69(4): 245-263

Banks, R.B. (2013). Organizational climate, citizenship, and effectiveness in a public liberal arts institution. Dissertation for Doctor of Philosophy.Alabama University.

Chiaburu, Dan S. and Byrne, Zinta S. (2009) Predicting OCB Role Definitions: Exchanges with the Organization and Psychological. Journal of Business and Psychology. Vol. 24 (2): 201-214.

García-Carbonell, N., Martin-Alcazar, F. and Sanchez-Gardey, G. (2014), Deepening the consequences of double fit for organisational performance: the moderating role of employees' perceptions on the human resource management system,ManagementResearch Review, Vol. 37 No. 12: 1026-1048.

Ghozali, Imam (2008). Structural Equation Modeling Metode Alternatif dengan Partial Least Square. Semarang: Badan Penerbit Universitas Diponegoro.

Iqbal, H. K., Aziz, U., \& Tasawar, A. (2012). Impact of Organizational Justice on Organizational Citizenship Behavior: an Empirical Evidence from Pakistan. World Applied Sciences Journal. Vol. 19(9): 1348-1354

Jafari, P., \& Bidarian, S. (2012). The Relationship between Organizational Justice and Organizational Citizenship Behavior. ProcediaSocial and Behavioral Sciences. Vol 47: 1815-1820.

Jones, Ambrose \& Norman, Carolyn Strand (2010) "Healthy Lifestyle as a Coping Mechanism for Role Stress in Public Accounting". Behavioral research in accounting. Vol. 22 (1): 21-41.

Kundu, K. (2007). Development of the conceptual framework of organizational climate. Vidyasagar University Journal of Commerce. Vol. 12: 99-108.

Lo, M.C., Ramayah, T. and Hui, J.K. (2006), "An investigation of leader member exchange effects on organizational citizenship behaviour in Malaysia", Journal of Business andManagement, Vol. 12 (1): 5-23.

Mansoor, Narmeen. et al. (2012) Exploring Organizational Citizenship Behavior and its Critical Link to Employee Engagement for Effectual Human Resource Management in Organizations. Mediterranean Journal of Social Sciences. Vol. 3 (1): 2039-2117.

Mathuveloo, R., Basbous, O.K., Teoh, A.P., \& Choi, S.L. (2013). Antecedents of employee engagement in the manufacturing sector. American Journal of Applied Sciences, 10 (12): 1546-1552.

McBain, R. (2007). The practice of engagement : Research into current employee engagement practice. Strategic HR Review. Vol. 6 (6): 16-19.

Mujiasih, E., \& Ratnaningsih, I.Z. (2012). Increase Work Engagement through transformational leadership style and organizational culture. Journal of Psychology.

Ocampo, Lanndon. et al. (2018) A historical review of the development of organizational citizenship behavior (OCB) and its implications for the twenty-first century. Personnel Review. Vol. 47 (4): 821-862.

Prihatsanti, Unika \& Sari, Kartika. (2010) The relationship between organizational climate and organizational citizenship behavior in public elementary school teachers in Mojolaban Sukaharjo sub-district. Journal of Psychology. Vol.7 (1).

Priliantari, Yulita Daru. (2010) Interpersonal communication and the formation of an organizational climate in higher education (studies in the communications and high school of the Tarakinata Jakarta secretariat)Tesis. PPs-UI.

Purba, Debora E. (2015) Personality and organizational citizenship behavior in Indonesia: The mediating effect of affective commitment. Asian Business \& Management. Vol. 14 (2): 147-170.

Rasheed, A., Khan, S., and Ramzan, M. (2013). Antecedents and consequences of employee engagement: The case of Pakistan. Journal of Business Studies Quarterly. Vol 4 (4): 183-200. 
Rurkkhum, Suthinee \& Kenneth R. Bartlett (2012) The relationship between employee engagement and organizational citizenship behaviour in Thailand.Human Resource Development International. Vol. 15 (2): 157-174.

Sarangi, S. (2012). An exploratory study of employee engagement initiatives in the Indian banking sector. SIES Journal of Management. Vol 8 (1): 99-22.

Silva, H., \& Madhumali, K. (2014). Organizational Justice and Organizational Citizenship Behavior: a Study of Public Sector Organizations in Western Province. Kelaniya Journal of Human Resource Management, 2(1/2): $1-14$

Sugiyono. (2015). Quantitative Research Methods and R ED.Bandung : CV. Alpha Beta.

Testa, Francesco. et al. (2018) Predictors of organizational citizenship behavior in relation to environmental and health $\mathcal{E}$ safety issues. The International Journal of Human Resource Management. Vol. 10.

Vigoda-Gadot. Eran. (2007) Redrawing the Boundaries of OCB? An Empirical Examination of Compulsory Extra-Role Behavior in the Workplace. Journal of Business and Psychology. Vol. 21 (3): 377-405.

Wickham, Mark \& Parker, Melissa. (2007) Reconceptualising organisational role theory for contemporary organisational contexts. Journal of Managerial Psychology. Vol. 22 (5): 440-464

Wirawan. (2008). Organizational Culture and Climate. Jakarta : Salemba Empat.

Zulyanti, Indah. (2014). Effect of organizational climate, job characteristics and employee engagement on organizational citizenship behavior (studies in xyz DKI Jakarta institutions)Tesis. PPs-UI.

Zhang, Yucheng, Yongxing Guo b, \& Alexander Newman c. (2017) “Identity judgements, work engagement and organizational citizenship behavior: The mediating effects based on group engagement model" Tourism Management. Volume 61. 